
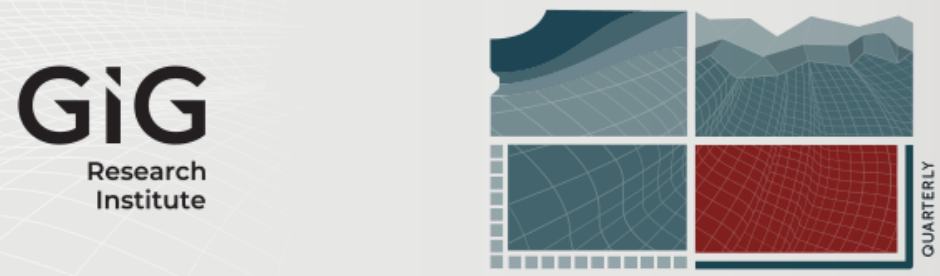

JOURNAL

OF

SUSTAINABLE

MINING

\title{
Selection mining methods via multiple criteria decision analysis using TOPSIS and modification of the UBC method
}

Author(s) ORCID Identifier:

Mahrous Ali Mohamed Ali (iD) 0000-0001-9369-0765

Jong-Gwan Kim (D) 0000-0002-2131-1946

Follow this and additional works at: https://jsm.gig.eu/journal-of-sustainable-mining

Part of the Mining Engineering Commons

\section{Recommended Citation}

Ali, Mahrous Ali Mohamed and Kim, Jong-Gwan (2021) "Selection mining methods via multiple criteria decision analysis using TOPSIS and modification of the UBC method," Journal of Sustainable Mining: Vol. 20 : Iss. 2 , Article 1.

Available at: https://doi.org/10.46873/2300-3960.1054

This Research Article is brought to you for free and open access by Journal of Sustainable Mining. It has been accepted for inclusion in Journal of Sustainable Mining by an authorized editor of Journal of Sustainable Mining. 


\title{
Selection mining methods via multiple criteria decision analysis using TOPSIS and modification of the UBC method
}

\begin{abstract}
Mine designers often face difficulties in selecting an appropriate mining method; however, such a method should be selected based on ore and rock characteristics. The selection of mining methods can be considered a type of multi-criteria decision making, and this depends on many factors used in the selection process. The general method used in this field is the University of British Columbia (UBC) method, which determines the criteria of the properties that are compared to determine the best and worst of several mining methods. In this paper we used as new technique which define as Technique for Order of Preference by Similarity to Ideal Solution (TOPSIS). The criteria considered in the UBC method include general shape, ore thickness, ore plunge, and grade distribution, beside the rock quality designation (RQD), and the rock substance strength (RSS). This paper presents an improved TOPSIS method based on experimental design. Additionally, this paper will introduce a modified version of the UBC method that can be employed based on Excel sheet. The best mining methods is cut and fill Stoping and Top slicing with the same rank equal 0.72 , and the second-best mining method is Square set Stoping with rank equal 0.65 .
\end{abstract}

\section{Keywords}

TOPSIS, UBC method, Mining methods selection, Multiple-criteria decision making

\section{Creative Commons License}

\section{cC) (7)}

This work is licensed under a Creative Commons Attribution 4.0 License.

\section{Cover Page Footnote}

The authors convey many thanks to the management of Boleo mine (Mexico) for their support and provide them with data to achievement the paper. 


\title{
Selection mining methods via multiple criteria decision analysis using TOPSIS and modification of the UBC method
}

\author{
Mahrous A.M. Ali ${ }^{a}$, Jong-Gwan Kim ${ }^{\text {b,* }}$ \\ ${ }^{a}$ Mining and Petroleum Engineering Department, Faculty of Engineering Al-Azhar University, Egypt \\ ${ }^{\mathrm{b}}$ Department of Energy \& Resources Engineering, Chonnam National University, South Korea
}

\begin{abstract}
Mine designers often face difficulties in selecting an appropriate mining method; however, such a method should be selected based on ore and rock characteristics. The selection of mining methods can be considered a type of multi-criteria decision making, and this depends on many factors used in the selection process. The general method used in this field is the University of British Columbia (UBC) method, which determines the criteria of the properties that are compared to determine the best and worst of several mining methods. In this paper we used as new technique which defines as Technique for Order of Preference by Similarity to Ideal Solution (TOPSIS). The criteria considered in the UBC method include general shape, ore thickness, ore plunge, and grade distribution, beside the rock quality designation (RQD), and the rock substance strength (RSS). This paper presents an improved TOPSIS method based on experimental design. Additionally, this paper will introduce a modified version of the UBC method that can be employed based on Excel sheet. The best mining methods is cut and fill stoping and top slicing with the same rank equal 0.72, and the second-best mining method is square set stoping with rank equal 0.65 .
\end{abstract}

Keywords: TOPSIS, UBC method, mining methods selection, multiple-criteria decision making

\section{Introduction}

$\mathrm{O}$ re extraction processes are designed with regard to surface or underground mining methods. These techniques depend on the depth, stripping ratio, and other parameters. Furthermore, the optimal use of underground resources is related to the choice of underground mining methods; many factors are taken into consideration in underground mining method; these include safety, mine planning, ventilation system, reduced maintenance costs, and planning production [1,2]. According to the criteria of University of British Columbia (UBC) method for selecting appropriate mining methods, a good selection will be made. Another issue pertains to the manner in which the methodology should be used to achieve high accuracy and easy application. All results should be aggregated to analyse the decision before it is applied. Many conventional methods consider only a limited number of criteria; therefore, in the decisionmaking process; there is a need for alternative methods, that can consider all known criteria related to selecting underground mining methods. This is because once a mining method is selected, it is nearly impossible to change it owing to the high costs and losses entailed. Thus, it is very important to re-analyse a decision before it is carries out $[3,4]$. The method that decision makers generally use for this is a sensitivity analysis of the final decision. Mining method selection underlies every mining operation and is essential for estimating the capital and operating costs of alternatives such that economic returns are maximized. This selection is also an important task in

Received 4 February 2021; revised 23 April 2021; accepted 23 April 2021.

Available online 25 May 2021.

* Corresponding author.

E-mail address: kimjg@jnu.ac.kr (J.-G. Kim). 
mine management because of its effect on operational cost; it is also an integral part of mine planning and design. Most importantly, using the appropriate mining method increases the safety of employees and secures production [5]. Despite this, mining method selection is not a welldefined process because it involves the interaction of several subjective factors or criteria. In this process, several controllable and uncontrollable parameters should be accounted for [6], and they should be determined according to scientific and technical studies for individual ore deposits [7-10]. The numerous effective factors involved in the selection of an appropriate mining method, complicate this process. The selection method for exploiting fluorine deposits, similar to those used for other deposits, includes modelling followed by examining alternative for mining treatment. Several qualitative and quantitative methods have been developed to evaluate suitable mining methods for ore deposits based on their geometry (depth, shape, thickness, dip), rock quality (ore zone and host rock competency, i.e., structures, stress, stability), ore variability (uniformity, continuity, grade distribution) and related economics factors (ore recovery, ore value and mine recovery, productivity, capital, operating costs) [11-13]. Many citations are provided herein regarding the main sequences employed in all mining methods and the related criteria. This study will focus on the modification of the UBC method using the function in an Excel sheet integrated with the UBC criteria for all mining methods. All criteria indexes from the UBC method will be defined in Excel sheets related to all rock characterizations and mining methods. In this regard [14], the use of multi-criterion decision-making overcomes many of the shortcomings of the aforementioned studies [15-19].

In this article we applying the TOPSIS technique, TOPSIS is defined related to the main concept of the best decision making which lead to selected the closed ideal solution and faraway from the nonideal solution as mentioned This technique depends on one that maximum or minimum for the benefit criteria which related to positive or negative ideal solutions. TOPSIS is compare between positive and negative solution to find out the distance between alternative solutions. There are many researchers developed the TOPSIS from Ref. [20]. They are focused on creating the weight for each criterion, scoring normalization for each criterion and estimating the geometric distance between each alternative and the ideal alternative, to a carried out the best value for each criterion.

\section{Site investigation and data collection}

Geotechnical characterization of the Boleo mine (Mexico) field involved evaluating its various geological structural features and depositional environments. The mineral-bearing zones of interest in the area are bedded clay seams with a slight dip known locally as mantos and an overlying brecciated zone. There are three mines denoted M303, M303S, and M303C, at this site. To circumvent the area of Manto 3, step mining was used to reach the ore body after excavation through its upper interburden. Severe abrasions and pillar damage were caused when conglomerate and repeated grading were supporting the lateral pressure of the mine. Crack displacements and cement injections were measured. In addition, water did not penetrate through cracks during the rainy season. For short wall mining, the main gateway was excavated in the Manto 3 layer; this mine has two panels. One section of panel SW1 was $80 \mathrm{~m}$ width and $2.4 \mathrm{~m}$ high; currently, it is approximately $90 \mathrm{~m}$ length, and thus produces a volume of approximately $17,280 \mathrm{~m}^{3}$ of

Table 1. Characterization of rock collected from the mine site.

\begin{tabular}{llll}
\hline Ore property & & Description & Magnitude \\
\hline General shape & & T, Tabular & - \\
Ore thickness, $\mathrm{m}$ & & N, Narrow & 15 \\
Ore plunge, degree & & G, Gradational & 70 \\
Grade distribution & & SH, Shallow & - \\
Depth below surface, m & Ore zone & M, Moderate & 100 \\
Rock quality designation (RQD, \%) & Hanging wall & VW, very weak & 60 \\
& Foot wall & VW, very weak & 35 \\
Rock substance strength (RSS) & Ore zone & VW, very weak & 35 \\
& Hanging wall & W, weak & 35 \\
& Foot wall & W, weak & 25 \\
\end{tabular}


extracted ore. Table 1 lists the proprieties of the rock in the studied area, including data on ore thickness, shape, ore plunge, grade distribution, depth, and rock mass classification.

\section{Methodology}

The UBC method was devolved and established and developed by Miller to address the need to improve the Nicholas technique. New additions by Miller include assigning a -10 value a negative weight without completely discarding any alternative. Rock characterizations particularly the mechanical values were also modified. Tomich provides more details as shown in Fig. 1 [15]. We are converted the UBC criteria to weight and rate, the weight depends on the properties to mining methods (highest weight is advantages and lowest is disadvantages corresponding to mining methods) and the rate depends on the real geo-technical geometric, and economic factors related to mine filed investigation, all criteria are presented Tables 2 and 3.

TOPSIS technique assumes that monotonous criteria increase or decrease. Which depends on normalization as a basic factor even though takes in consideration an odd dimension in multi-criteria cases. TOPSIS technique is good method to comparison between criteria as considered poor results in other issue. That results provide us in realistic form of modelling than other methods, take in consideration the alternatives related to include or exclude alternative solutions.

One model uses a total of 36 criteria that were classified into six main groups by Hartman and Mutmansky to analyse an underground mining method selection (UMMS) problem in detail [3]. These criteria are listed in Table 3. However, using this model, also increased the number of pair-wise comparison matrices. The alternatives of the Analytical Hierarchy Processing (AHP) models and the fuzzy multiple attribute decision-making (FMADM) are determined based on the UBC approach used by various researcher [21-34]. The UBC approach is simply a modified version of the Nicholas approach; it numerically ranks the characteristics of the ore geometry and rock mechanics for the ore zone, footwall, and hanging wall of the target deposits. The rankings are then summed where the higher rankings correspond to the more favourable methods. Each ranking consists of a number, such as a number from " 0 to 6 " or " 10 , -49 ". A rank of " -49 " corresponds to a mining method that is not feasible and the methods is therefore eliminated; a rank of "0" suggests strongly that a particular characteristic makes given mining method less attractive than others; and a rank of " 6 " indicates that the corresponding mining methods possesses a very favourable characteristic. To determine the set of valid alternatives, the underground mining method selection (UMMS) uses the final UBC ranking.

\section{Modifications to the University of British Columbia (UBC) method}

The discussion and illustration of the UBC method in the prior section clarify it before the modifications are discussed in this section. The main criterion for this technique is measuring the stratification of all mechanical and other properties

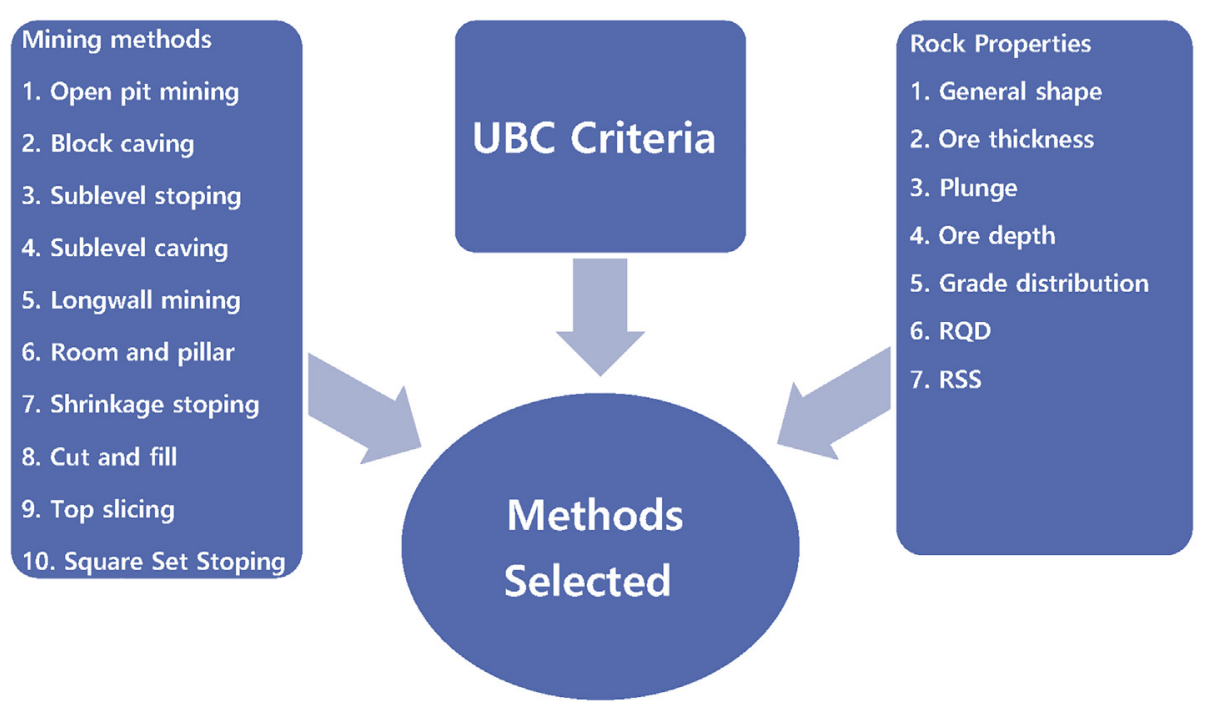

Fig. 1. All criteria and mining methods. ${ }^{*} R Q D$ - rock quality designation, RSS - rock substance strength. 
Table 2. Assignment of the weights of the various parameters according to mining methods.

\begin{tabular}{|c|c|c|c|c|c|c|c|c|c|c|c|c|}
\hline & \multicolumn{2}{|c|}{$\begin{array}{l}\text { Parameter/mining } \\
\text { methods }\end{array}$} & $\begin{array}{l}\text { Open } \\
\text { pit }\end{array}$ & $\begin{array}{l}\text { Block } \\
\text { caving }\end{array}$ & $\begin{array}{l}\text { Sublevel } \\
\text { stoping }\end{array}$ & $\begin{array}{l}\text { Sublevel } \\
\text { caving }\end{array}$ & longwall & $\begin{array}{l}\text { Room and } \\
\text { pillar }\end{array}$ & $\begin{array}{l}\text { Shrinkage } \\
\text { stopping }\end{array}$ & $\begin{array}{l}\text { Cut and } \\
\text { fill stoping }\end{array}$ & $\begin{array}{l}\text { Top } \\
\text { slicing }\end{array}$ & $\begin{array}{l}\text { Square set } \\
\text { stoping }\end{array}$ \\
\hline 1 & \multicolumn{2}{|c|}{ General shape } & 0.8 & 0.8 & 0.6 & 0.6 & 0 & 0 & 0 & 0.2 & 0.2 & 0 \\
\hline 2 & \multicolumn{2}{|c|}{ Ore thickness, m } & 0.8 & 0.8 & 0.6 & 0.8 & 0 & 0 & 0 & 0 & 0.2 & 0 \\
\hline 3 & \multicolumn{2}{|c|}{ Grade distribution } & 0.6 & 0.6 & 0.8 & 0.6 & 0.8 & 0.8 & 0.6 & 0.4 & 0.4 & 0 \\
\hline 4 & \multicolumn{2}{|c|}{$\begin{array}{l}\text { Depth below } \\
\text { surface, } \mathrm{m}\end{array}$} & 0.8 & 0.4 & 0.6 & 0.6 & 0.4 & 0.6 & 0.6 & 0.4 & 0.4 & 0.2 \\
\hline 5 & \multicolumn{2}{|c|}{ Plange } & 0.2 & 0.8 & 0.8 & 0.8 & 0 & 0 & 0.8 & 0.8 & 0 & 0.4 \\
\hline 6 & \multirow[t]{3}{*}{ RQD } & Ore zone & 0.6 & 0 & 0.8 & 0 & 0.4 & 09 & 0.6 & 0.6 & 0 & 0 \\
\hline 7 & & Hanging wall & 0.8 & 0.4 & 0.8 & 0.4 & 0.6 & 0.9 & 0.8 & 0.6 & 0.6 & 0 \\
\hline 8 & & Foot wall & 0.8 & 0.4 & 0.6 & 0.6 & 0 & 0 & 0.6 & 0.4 & 0.4 & $\begin{array}{l}0 \\
00\end{array}$ \\
\hline 9 & \multirow[t]{3}{*}{ RSS } & Ore zone & 0.6 & 0 & 0.8 & 0.4 & 0.2 & 0.9 & 0.8 & 0.6 & 0 & 0 \\
\hline 10 & & Hanging wall & 0.8 & 0 & 0.6 & 0.250 & 0.4 & 0.9 & 0.8 & 0.4 & 0.4 & 0 \\
\hline 11 & & Foot wall & 0.8 & 0.2 & 0.6 & 0.4 & 0 & 0 & 0.6 & 0.4 & 0.25 & 0 \\
\hline
\end{tabular}

Table 3. Assigned ratings to the different ranges of parameters.

\begin{tabular}{|c|c|c|c|c|c|}
\hline \multirow[t]{2}{*}{ Parameter } & \multicolumn{5}{|l|}{ Rating } \\
\hline & 0 & 0.4 & 0.6 & 0.8 & 1 \\
\hline \multirow[t]{2}{*}{ General shape } & Irregular & $\begin{array}{l}\text { Platy/Tabular W/Depth } \\
\text { no exceed } 35 \mathrm{~m}\end{array}$ & $\begin{array}{l}\text { Platy/Tabular W/Depth } \\
\text { no exceed } 30 \mathrm{~m}\end{array}$ & $\begin{array}{l}\text { Platy/Tabular W/Depth } \\
\text { no exceed } 25 \mathrm{~m}\end{array}$ & $\begin{array}{l}\text { Equal } \\
\text { dimensions }\end{array}$ \\
\hline & Very low & low & Medium & High & Very high \\
\hline \multirow[t]{2}{*}{ Ore thickness, m } & $<3$ & $3-10$ & $10-30$ & $30-100$ & $>100$ \\
\hline & Very narrow & Narrow & Intermediate & thick & Very thick \\
\hline \multirow[t]{2}{*}{ Plunge } & $>55$ & $45-55$ & $35-45$ & $20-35$ & $<20$ \\
\hline & steep & Sami steep & Intermediate & Sami flat & flat \\
\hline \multirow{2}{*}{$\begin{array}{l}\text { Depth below surface, } \\
\text { m }\end{array}$} & $>600$ & $300-600$ & $150-300$ & $70-150$ & $<70$ \\
\hline & Deep & Sami deep & Intermediate & Sami shallow & shallow \\
\hline \multirow{2}{*}{$\begin{array}{l}\text { Grade distribution, } \\
\%\end{array}$} & $<50$ & $50-70$ & $70-80$ & $80-99$ & 100 \\
\hline & erratic & un Uniformed & Medium & Sami Uniformed & Uniformed \\
\hline \multirow[t]{2}{*}{ Ore zone } & $<20$ & $30-40$ & $40-60$ & $60-80$ & $80-100$ \\
\hline & Very weak & Weak & Moderate & strong & Very strong \\
\hline \multirow[t]{2}{*}{ Ore zone } & $<5$ & $5-10$ & $10-15$ & $15-20$ & 20 \\
\hline & Very weak & Weak & Moderate & strong & Very strong \\
\hline
\end{tabular}

of the bedrock such that can be added to a new Excel sheet and linked with phenomena corresponding to all mining methods by using the TOPSIS technique, which can easily connect all the characterization bed layers e.g., thickness, plunge, depth, rock mass rating (RMR). The following example shows the manner in which the function and active link to all parameters can be prepared. Table 4 illustrate the weight and rate for every property, the weight mean if this property as advantages or disadvantages for mining methods as mention in UBC method, and the rate mean the actual property based on UBC scheme.

The final value will appear in the next file in the same Excel sheet as shown in Table 6. Decision makers can decide which method is suitable able to decide for a given mine based on the fact that a high value (nearest from 1) is assigned to the most preferred method, less to the next preference, and so on. All methods will be formulated according to the UBC method and linked cell in excel sheet with all properties. MCDM assume that, the issue was obeyed to $\mathrm{m}$ alternative, denotes the value assigned to the jth criterion of the ith alternative, $\mathrm{x}_{\mathrm{ij}}$ is the decision matrix. The equivalent weight of property has mentioned by $\mathrm{w}_{1}, \mathrm{w}_{2}, \ldots . \mathrm{w}_{\mathrm{n}}$, beside the TOPSIS processes are find out as five steps which follows by equations (1)-(5). Table 4 illustrated transformed approach criteria from UBC criteria all properties were weighted to near from 1. Table 5 is given the calculation normalized matrix according to Equation No. 1. Table 6 summarized the results of variables $X$ multiplied with weighted index for every property. Table 7 illustrated the positive ideal and negative ideal solutions and finally Table 8 is given the final results according to the Euclidean distance from the ideal worst and ranking. 
Table 4. Conversion the UBC criteria to new approach of weight and rate.

\begin{tabular}{|c|c|c|c|c|c|c|c|}
\hline weights/rates & $\begin{array}{l}0.1 \\
\text { General shape }\end{array}$ & $\begin{array}{l}0.4 \\
\text { Ore thickness, } \mathrm{m}\end{array}$ & $\begin{array}{l}0.6 \\
\text { Grade distribution }\end{array}$ & $\begin{array}{l}0.8 \\
\text { Depth below surface, } \mathrm{m}\end{array}$ & $\begin{array}{l}1 \\
\text { Plunge }\end{array}$ & $\begin{array}{l}0.3 \\
\text { RQD }\end{array}$ & $\begin{array}{l}0.4 \\
\text { RSS }\end{array}$ \\
\hline Open pit mining & 0.4 & 0.8 & 0.6 & 0.6 & 0.6 & 0.1 & 0.1 \\
\hline Block caving & 0.8 & 0.8 & 0.6 & 0.8 & 0.1 & 0.1 & 0.1 \\
\hline Sublevel stoping & 0.6 & 0.6 & 0.8 & 0.6 & 0.8 & 0.8 & 0.6 \\
\hline Sublevel caving & 0.8 & 0.4 & 0.6 & 0.6 & 0.4 & 0.6 & 0.6 \\
\hline Longwall & 0.2 & 0.8 & 0.8 & 0.8 & 0.1 & 0.1 & 0.8 \\
\hline Room and pillar & 0.6 & 0.1 & 0.8 & 0.1 & 0.4 & 9 & 0.6 \\
\hline Shrinkage stoping & 0.1 & 0.4 & 0.8 & 0.4 & 0.6 & 0.9 & 0.8 \\
\hline Cut and fill stoping & 0.8 & 0.4 & 0.6 & 0.6 & 0.1 & 0.1 & 0.6 \\
\hline Top slicing & 0.6 & 0.1 & 0.8 & 0.4 & 0.2 & 0.9 & 0.8 \\
\hline Square set stoping & 0.8 & 0.1 & 0.6 & 0.25 & 0.4 & 0.9 & 0.8 \\
\hline
\end{tabular}

Table 5. Normalized matrix.

\begin{tabular}{|c|c|c|c|c|c|c|c|}
\hline & $\begin{array}{l}\text { General } \\
\text { shape }\end{array}$ & Ore thickness, $\mathrm{m}$ & $\begin{array}{l}\text { Grade } \\
\text { distribution }\end{array}$ & $\begin{array}{l}\text { Depth below } \\
\text { surface, } m\end{array}$ & Plunge & RQD & RSS \\
\hline Open pit mining & 0.203858877 & 0.478947472 & 0.268328157 & 0.340092121 & 0.4341 & 0.0109 & 0.0499 \\
\hline Block caving & 0.407717753 & 0.478947472 & 0.268328157 & 0.453456161 & 0.0724 & 0.0109 & 0.0499 \\
\hline Sublevel stoping & 0.305788315 & 0.359210604 & 0.357770876 & 0.340092121 & 0.5789 & 0.087 & 0.2993 \\
\hline Sublevel caving & 0.407717753 & 0.239473736 & 0.268328157 & 0.340092121 & 0.2894 & 0.0653 & 0.2993 \\
\hline Longwall & 0.101929438 & 0.478947472 & 0.357770876 & 0.453456161 & 0.0724 & 0.0109 & 0.399 \\
\hline Room and pillar & 0.305788315 & 0.059868434 & 0.357770876 & 0.05668202 & 0.2894 & 0.9792 & 0.2993 \\
\hline Shrinkage stoping & 0.057259833 & 0.325515384 & 0.386694596 & 0.275208366 & 0.4835 & 0.0979 & 0.4 \\
\hline Cut and fill stoping & 0.407717753 & 0.239473736 & 0.268328157 & 0.340092121 & 0.0724 & 0.0109 & 0.2993 \\
\hline Top slicing & 0.305788315 & 0.059868434 & 0.357770876 & 0.226728081 & 0.1447 & 0.0979 & 0.399 \\
\hline Square set stoping & 0.407717753 & 0.059868434 & 0.268328157 & 0.14170505 & 0.2894 & 0.0979 & 0.399 \\
\hline
\end{tabular}

Table 6. Calculate Normalized Matrix multiplied with rate for every property.

\begin{tabular}{|c|c|c|c|c|c|c|c|}
\hline Methods/properties & General shape & Ore thickness, m & Grade distribution & Depth below surface, $\mathrm{m}$ & Plunge & RQD & RSS \\
\hline Open pit mining & 0.020385888 & 0.191578989 & 0.160996894 & 0.272073697 & 0.4341 & 0.0033 & 0.02 \\
\hline Block caving & 0.040771775 & 0.191578989 & 0.160996894 & 0.362764929 & 0.0724 & 0.0033 & 0.02 \\
\hline Sublevel stoping & 0.030578831 & 0.143684242 & 0.214662526 & 0.272073697 & 0.5789 & 0.0261 & 0.1197 \\
\hline Sublevel caving & 0.040771775 & 0.095789494 & 0.160996894 & 0.272073697 & 0.2894 & 0.0196 & 0.1197 \\
\hline Longwall & 0.010192944 & 0.191578989 & 0.214662526 & 0.362764929 & 0.0724 & 0.0033 & 0.1596 \\
\hline room and pillar & 0.030578831 & 0.023947374 & 0.214662526 & 0.045345616 & 0.2894 & 0.2938 & 0.1197 \\
\hline Shrinkage stoping & 0.005725983 & 0.130206153 & 0.232016757 & 0.220166693 & 0.4835 & 0.0294 & 0.16 \\
\hline Cut and fill stoping & 0.040771775 & 0.095789494 & 0.160996894 & 0.272073697 & 0.0724 & 0.0033 & 0.1197 \\
\hline Top slicing & 0.030578831 & 0.023947374 & 0.214662526 & 0.181382464 & 0.1447 & 0.0294 & 0.1596 \\
\hline Square set stoping & 0.040771775 & 0.023947374 & 0.160996894 & 0.11336404 & 0.2894 & 0.0294 & 0.1596 \\
\hline
\end{tabular}

Table 7. The positive ideal and negative ideal solutions.

\begin{tabular}{lllllll}
\hline $\mathrm{V}+$ & 0.005725983 & 0.023947374 & 0.160996894 & 0.045345616 & 0.0724 & 0.0033 \\
$\mathrm{~V}-$ & 0.040771775 & 0.191578989 & 0.232016757 & 0.362764929 & 0.5789 & 0.2938 \\
\hline
\end{tabular}

Table 8. Euclidean distance from the ideal worst and ranking.

\begin{tabular}{lllll}
\hline $\mathrm{Si}^{+}$ & $\mathrm{Si}^{-}$ & $\mathrm{P}_{\mathrm{i}}$ & Rank & \\
\hline 0.4589 & 0.3723 & 0.45 & 7 & Open pit mining \\
0.3607 & 0.6046 & 0.63 & 3 & Block caving \\
0.5799 & 0.2902 & 0.33 & 9 & Sublevel stoping \\
0.3393 & 0.4278 & 0.56 & 5 & Sublevel caving \\
0.3889 & 0.585 & 0.60 & 4 & Longwall \\
0.3807 & 0.4633 & 0.55 & 6 & Room and pillar \\
0.486 & 0.323 & 0.40 & 8 & Shrinkage stoping \\
0.2603 & 0.6564 & 0.72 & $\underline{1}$ & Cut and fill stoping \\
0.2178 & 0.5655 & 0.72 & $\underline{1}$ & $\underline{\text { Top slicing }}$ \\
0.2705 & 0.499 & 0.65 & $\underline{2}$ & Square set stoping \\
\hline
\end{tabular}

1. Normalize the decision matrix:

$$
\bar{X}_{i j}=\frac{X_{i j}}{\sqrt{\sum_{i=1}^{n} X_{i j}^{2}}}
$$

$r i j=x i j-m k=1 x 2 k j, i=1, \ldots, m ; j=1, \ldots, n$ where $r i j$ denotes the normalized value of $j$ th criterion for the $i$ th alternative $A i$.

2. Calculate the weighted normalized decision matrix: 
$V_{i j}=\bar{X}_{i j} \times W_{j}$

$v i j=w j$ ri $j, i=1, \ldots, m ; j=1, \ldots, n(2)$, where $w_{j}$ is the weight of the $j$ th criterion or attribute.

3. Determine the positive ideal and negative ideal solutions:

$S_{i}^{+}=\left[\sum_{j=1}^{m}\left(V_{i j}-V_{j}^{+}\right)^{2}\right]^{0.5}$

4. Calculate the Euclidean distance from the ideal worst

$S_{i}^{-}=\left[\sum_{j=1}^{m}\left(V_{i j}-V_{j}^{-}\right)^{2}\right]^{0.5}$

\section{Calculate Performance Score and ranking}

$P_{i}=\frac{S_{i}^{-}}{S_{i}^{+}+S_{i}^{-}}$

\section{Conclusion}

The results showed that, selecting a mining method would depend on many criteria, all of which are related to safety and economic considerations. The modification of the UBC method focused on linking all parameters related to all criteria in a simple manner and obtaining accurate final results. The final results provide indicators using which decision makers can choose between different mining methods based on the total points given to all ore properties. The best mining methods is cut and fill stoping and top slicing with the same rank equal 0.72 , and the second-best mining method is square set stoping with rank equal 0.65 , the pattern continues as shown in Table 8. This modified method was applied to other case and good results were obtained; further, it is easy input and output all data and solutions.

\section{Ethical statement}

The authors state that the research was conducted according to ethical standards.

\section{Funding body}

This research received no external funding.

\section{Conflicts of interest}

None declared.

\section{Acknowledgement}

The authors convey many thanks to the management of Boleo mine (Mexico) for their support and provide them with data to achievement the paper.

\section{References}

[1] Hoek E, Brown ET. Underground excavations in rock. London: Institution of Mining and Metallurgy; 1980. p. 527.

[2] Harman HL. Introductory mining engineering. New Jersey: John Wiley; 1987.

[3] Hartman HL, Mutmansky JM. Introductory mining engineering. New Jersey: John Wiley; 2002.

[4] Alpay Serafettin, Yavuz Mahmut. Underground mining method selection by decision making tools. Tunn Undergr Space Technol 2009;24:173-84.

[5] Ataei M. Multicriteria selection for alumina-cement plant location in East- Azerbaijan province of Iran. J S Afr Inst Min Metall 2005;105:507-14.

[6] Peskens TW. Underground mining method selection and preliminary techno-economic mine design for the Wombat orebody, Kylylahti deposit, Finland. Master thesis. Section for Resource Engineering Department of Geoscience \& Engineering Delft University of Technology; 2013.

[7] Bitarafan MR, Ataei M. Mining method selection by multiple criteria decision-making tools. J S Afr Inst Min Metall 2004; 104:493-8.

[8] Boshkov SH, Wright FD. Basic and parametric criteria in the selection, design and development of underground mining systems. SME Mining Engineering Handbook. New York: SME-AIME; 1973.

[9] Laubscher DH. Selection of mass underground mining methods. Design and operation of caving and sublevel stoping mines. New York: SME-AIME; 1981.

[10] Yavuz M, Alpay S. Mining method selection by multiple criteria decision-making tool by M.R. Bitarafan and M. Ataei. J SAIMM 2007;104(9):493-8.

[11] Karadogan A, Bascetin A, Kahriman A, Gorgun S. A new approach in selection of underground mining method. In: Proceeding of the international conference-modern management of mine producing, geology and environment protection; 2001. p. 171-83.

[12] Yavuz M, Iphar M, Once G. The optimum support design selection by using AHP method for the main haulage road in WLC Tuncbilek colliery. Tunn Undergr Space Technol 2008; 23:111-9.

[13] Samanta B, Sarkar B, Murherjee SK. Selection of opencast mining equipment by a multi-criteria decision-making process. Trans Inst Min Metall A 2002;111:A136-42.

[14] Kahriman A, Ceylanoglu A, Demirci A, Arpaz E, Gorgulu K. Selection of optimum underground mining method for Eskisehir-Karaburun chromite ore (in Turkish). In: Proceeding of the 3rd national rock mechanics symposium; 1996. p. 47-60.

[15] Miller-Tait L, Panalkis R, Poulin R. UBC mining method selection. In: Proceeding of the mine planning and equipment selection symposium; 1995. p. 163-8.

[16] Bascetin A, Kesimal A. The study of a fuzzy set theory for the selection of an optimum coal transportation system from pit to the power plant. Int J Surf Min Reclamat Environ 1999;13: 97-101.

[17] Elevli B, Demirci A. Multicriteria choice of ore transport system for an underground mine: application of PROMETHEE methods. J S Afr Inst Min Metall 2004;104: 251-6.

[18] Saaty TL. Fundamentals of decision making and priority theory with the analytic Hierarchy process. Pittsburgh: RWS; 2000. 
[19] Nicholas DE. Method selection - a numerical approach. Design and operation of caving and sublevel stoping mines. New York: SME-AIME; 1981.

[20] Wang Peng, Zhu Zhouquan, Huang Shuai. The use of improved TOPSIS method based on experimental design and Chebyshev regression in solving MCDM problems. 2014 J Intell Manuf 2017;28:229-43.

[21] Yavuz M, Alpay S. EQS: a computer software using fuzzy logic for equipment selection in mining engineering. J SAIMM 2006;106(1):63-70. 107, 138.

[22] Robert Tomich Alexander. An evaluation procedure for new deposits in brownfield underground mines. Master degree. Ontario, Canada: Queen's University Kingston; 2020.

[23] Acaroglu O, Ergin H, Eskikaya S. Analytical hierarchy process for selection of road headers. J S Afr Inst Min Metall 2006;106:569-75.

[24] Acaroglu O, Feridunoglu C, Tumac D. Selection of road headers by fuzzy multiple attribute decision making method. Trans Inst Min Metall 2006;115:A91-8.

[25] Bellman RE, Zadeh LA. Decision making in a fuzzy environment. Manag Sci 1970;17:141-64.

[26] Bieniawski ZT. Engineering rock mass classification. New York.: John Wiley \& Sons; 1989. p. 237.
[27] Chen C, Klein CM. An efficient approach to solving fuzzy MADM problems. Fuzzy Set Syst 1997;88:51-67.

[28] Kazakidis VN, Mayer Z, Scoble MJ. Decision making using the analytic hierarchy process in mining engineering. Trans Inst Min Metall 2004;113:A30-42.

[29] Kesimal A, Bascetin A. Application of fuzzy multiple attribute decision making in mining operations. Miner Resour Eng 2002;11:59-72.

[30] Riberio RA. Fuzzy multiple attribute decision making: a review and new preference elicitation techniques. Fuzzy Set Syst 1996;78:155-81.

[31] Saaty TL. The analytic Hierarchy process. Pittsburgh: McGraw-Hill; 1980.

[32] Triantaphyllou E, Sanchez A. A sensitivity analysis approach for some deterministic multi-criteria decision-making methods. Decis Sci J 1997;28:151-94.

[33] Yager RR. Fuzzy decision making including unequal objectives. Fuzzy Set Syst 1978;1:87-95.

[34] Witten IH, Frank E, Hall MA, Pal CJ. Data mining fourth edition: practical machine learning tools and techniques. 2016. 